\title{
ADDITIONS TO THE FLORA OF MANITOBA AND OTTERBURNE AREA
}

JEAN-PAUL BERNARD, Herbier Louis-Marie, Université Laval, Québec

The first is new to Manitoba.

RED-ROOTED UMBRELLA-SEDGE

(Cyperus erythrorhizos Mühl.) Salmonia Channel S of Winnipeg Lake, moist area, 27 August 1961. B61-51 (QFA) identified by B. Boivin and $\mathrm{C}$. Roy, Indigenous and largely distributed in U.S.A. In Canada, known in few localities in southern Ontario (Scoggan 1978) also known from southern B.C. ${ }^{3}$

Seems native in southern Ontario where it is known from Grimby (DAO) in Lincoln County, Saint Williams and Long Point (DAO, OAC, TRT) in Norfolk County, Stoney Creek (DAO) in Wentworth County, and Pointe aux Pins (MTMG) in Kent County. Also reported for Lambton County by Gaiser 1966 and Scoggan 1978 and for Waterloo County by Scoggan 1978 . Perhaps only adventive elsewhere in Canada.

The remaining are additions to the Flora of the Otterburne area. ${ }^{2}$

\section{WOOD ANEMONE}

(Anemone quinquefolia L. var. interior Fern.) - Woods along Rat River, Otterourne, 13 June 1959, B59-24 (QFA).

\section{SUGAR BEET}

Beta vulgaris L. var. crassa Alef.) Niverville, sprouting in a ditch near to a ield of sugar beet, 9 July 1959, B59-81 (FA). No doubt a casual and evanesent escape.

\section{IELD CHICKWEED}

Cerastium arvense $L$. var. viscidulum iremli) - Railway bank, Otterburne, 15 une 1959, B59-27 (QFA).

\section{COMMON FUMITORY}

(Fumaria officinalis L.) - Roadside 6 miles $E$ of Otterburne 15 July 1959, B59-116 (QFA).

\section{CELERY-LEAVED CROWFOOT}

(Ranunculus sceleratus L. f. natans Gluck) - Roadside 6 miles $E$ of Otterburne, 15 July 1959, B59-115 (QFA).

\section{SPANGLETOP}

(Scolochloa festucacea (Willd.) Link) Railway bank $21 / 2$ miles $\mathrm{N}$ of Otterburne, 9 July 1959, B59-78; also in the same date: roadside 3 miles $\mathrm{N}$ of Otterburne. B59-88 (QFA)

\section{LANCE-LEAVED LOOSESTRIFE}

(Steironema hybridum (Michx.) Raf.) Roadside 3 miles NE of Otterburne, 9 July 1959, B59-103 (QFA).

'CESKA, A. \& O. CESKA. 1980. Additions to the Flora of British Columbia, Can. Field-Nat. 94 (1):69-74.

¿LOVE, D. \& J.P. BERNARD. 1959. Flora and vegetation of the Otterburne area, Manitoba, Canada, Sv. Bot. Tidskr. 53 (4):335-461.

${ }^{3}$ SCOGGAN, H.J. 1978. The Flora of Canada, Part 2, 93-545; Part 3, 5471115. National Museum of Canada.

EDITOR'S NOTE: The abbreviations used above refer to the following herbaria: DOA = Dept. of Agriculture in Ottawa; MTMG = McGill University in Montreal; OAC = University of Guelph; QFA = Herbier Louis-Marie, University of Laval; TRT $=$ Dept. of Botany, University of Toronto. 